\title{
46. SYNTHESIS OF LEG 64 BIOSTRATIGRAPHY ${ }^{1}$
}

\author{
Marie-Pierre Aubry, ${ }^{2}$ Yasumochi Matoba,${ }^{3}$ Adolfo Molina-Cruz,,${ }^{4}$ and Hans Schrader ${ }^{5}$
}

\section{INTRODUCTION}

During Leg 64 of the Deep Sea Drilling Project, Sites 474-476 were drilled off the tip of southern Baja California, on a transect from oceanic to continental crust. The major objectives were a study of the early postrifting subsidence history of the Gulf and a delineation of the transition from oceanic to continental crust. Sites 477-481 were drilled in the Guaymas Basin in order to investigate the paleooceanography and biostratigraphy of an active, spreading basin and the nature of the oceanic crust that is currently being generated. Sites 477 and 481 were located on the south and north rifts, respectively, and Site 478 on the basin floor northwest of the south rift, $20 \mathrm{~km}$ from Site 477 . Sites 479 and 480 were drilled on the continental slope, in the oxygen-minimum zone (Fig. 1).

Chapters in Volume 64, Pt. 2, VI, reported upon the biostratigraphy, paleontology, and paleobiogeography of the sediments recovered during Leg 64 . The biostratigraphic findings are summarized here.

Four microfossil groups contributed to dating the sediments on board the ship. Calcareous nannofossils provided the major biostratigraphic control at Sites 474 , 475 , and 476 , whereas biostratigraphy at the other sites relied mostly on diatoms. Radiolarians were very rare in the sediments from the Guaymas Basin but frequent at Sites 474,475 , and 476 , where radiolarian biostratigraphy confirmed that based upon calcareous nannofossils. Planktonic foraminifers provided complementary biostratigraphic data for sediments recovered from the Guaymas Basin, in particular from Site 479.

In Figures 2-8, the distribution of the Pliocene and Pleistocene sediments is shown with the calcareous nannofossil, radiolarian, and diatom datum levels and planktonic foraminiferal evidences, and their estimated chronology.

\section{OCCURRENCE OF FOSSIL GROUPS}

The sediments recovered during Leg 64 were highly fossiliferous except for those rendered barren by thermal alteration. The diversity of the fossil groups repre-

\footnotetext{
${ }^{1}$ Curray, J. R., Moore, D. G., et al., Init. Repts. DSDP, 64: Washington (U.S. Govt. Printing Office).

${ }_{2}$ Laboratoire de Géologie des Bassins Sédimentaires, Université Pierre et Marie Curie, 75230 Paris, France, and Woods Hole Oceanographic Institution, Woods Hole, Massachusetts.

${ }_{4}^{3}$ Institute of Mining Geology, Akita University, Akita, Japan.

4 Instituto de Geología, Universidad de México, México, D. F., México.

5 School of Oceanography, Oregon State University, Corvallis, Oregon.
}

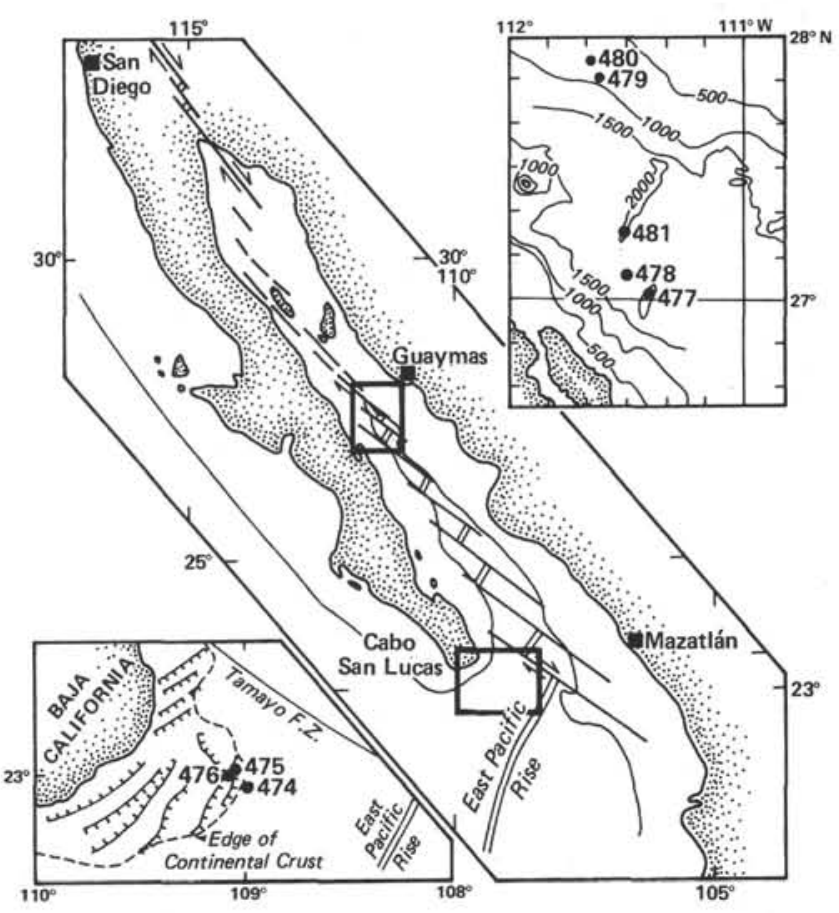

Figure 1. Location of Leg 64 sites.

sented was greater off the tip of southern Baja California than in the Guaymas Basin, where oceanic influences are restricted. At Sites 474, 475, and 476, calcareous nannofossils were abundant and generally well preserved. Radiolarians were frequent, except in the Pliocene sediments of Site 474. At Sites 475 and 476, diatom muds recovered above a conglomerate of continental origin contain abundant and moderately preserved diatoms and silicoflagellates. Planktonic foraminifers from these sites were not studied.

Diatom oozes and diatom muds were recovered mainly in the Guaymas Basin. At most sites the diatoms were well preserved, sometimes excellently preserved (Site 478), along with silicoflagellates. Calcareous nannofossils were diluted among the siliceous remains and except at Site 478 were moderately to poorly preserved. Planktonic foraminifers were abundant. Radiolarians were not studied.

\section{BIOSTRATIGRAPHY}

On board the ship, we chose to base the biostratigraphy mainly upon the recognization of datum levels, for convenience, since the main objectives of the biostratigraphers were to date the oldest sediments recov- 
ered at each site, particularly when the crust was reached, and to evaluate sedimentation rates through time at these sites.

Table 1 correlates the datum levels corresponding to each group-calcareous nannofossils, diatoms, and radiolarians. Table 2 gives the nature-last appearance datum (LAD), first appearance datum (FAD) and othersof the datum levels, their estimated ages, and their authors.

The difficulties related to recognition of the datum levels are discussed elsewhere in the specialty chapters for the different groups. Here we need only mention that calcareous nannofossil datum levels were difficult to establish in the turbidite sequences (Sites 474,475 , and 476) because of reworking and in the Guaymas Basin sediments because of poor preservation. Classical calcareous nannofossil zonation was used therefore only as complementary evidence.

No new datum levels were established for the calcareous nannofossils, diatoms, or silicoflagellates. Two new datum levels are suggested for the radiolarians (MolinaCruz, this volume, Pt. 2).

Figures 2-8 show the main datum levels and the estimated ages of the sediments at Leg 64 Sites.

\section{Oldest Sediments Recovered off the Tip of Southern Baja California}

Sites 474,475 , and 476 were drilled in order to reach the oceanic (Site 474) and the continental (Sites 475 and 476) crusts.

At Site 474 , basalt flows and sills were penetrated. The oldest available datum level, situated 60 meters above basalt flow 2A (Core 474-41), is the Discoaster surculus LAD, estimated to be $2.3 \mathrm{Ma}$. Even in the lowest sample obtained from Core 474-45, the Reticulofenestra pseudoumbilica LAD, estimated at $3.2 \mathrm{Ma}$, was not reached. Therefore, the oldest sediments overlying the oceanic crust at Site 474 are younger than 3.2 Ma and of late Pliocene age.

Holes at Sites 475 and 476 penetrated a conglomerate. Hole 476 also penetrated weathered granite beneath the conglomerate. Two meters of dolomitic mudstone (Site 475) and 3 meters of organic claystone and glauconitic sands (Site 476), overlying the conglomerate at both sites, were barren. Diatomaceous muds and oozes above the barren sediments were rich in diatoms, silicoflagellates, and calcareous nannofossils. Among the last at both sites, Ceratolithus acutus, a short-ranging index species, was found to characterize lowermost Pliocene sediments. The appearance of C. acutus (FAD) is estimated at $5 \mathrm{Ma}$. Its extinction (LAD), close to the appearance of C. rugosus, is at about $4.6 \mathrm{Ma}$. Therefore, the oldest fossiliferous sediments above the continental crust were deposited during the earliest Pliocene, between 5 and $4.6 \mathrm{Ma}$.

A major unconformity is present at both sites within the early Pliocene. Most of the Lower Pliocene sediments are missing. Above the diatomaceous muds and oozes, hemipelagic muds were deposited; they are assigned to the upper lower Pliocene calcareous nannofossil Zone NN15. The LAD of $R$. pseudoumbilica is
Table 1. Datum levels selected for Leg 64 biostratigraphy.

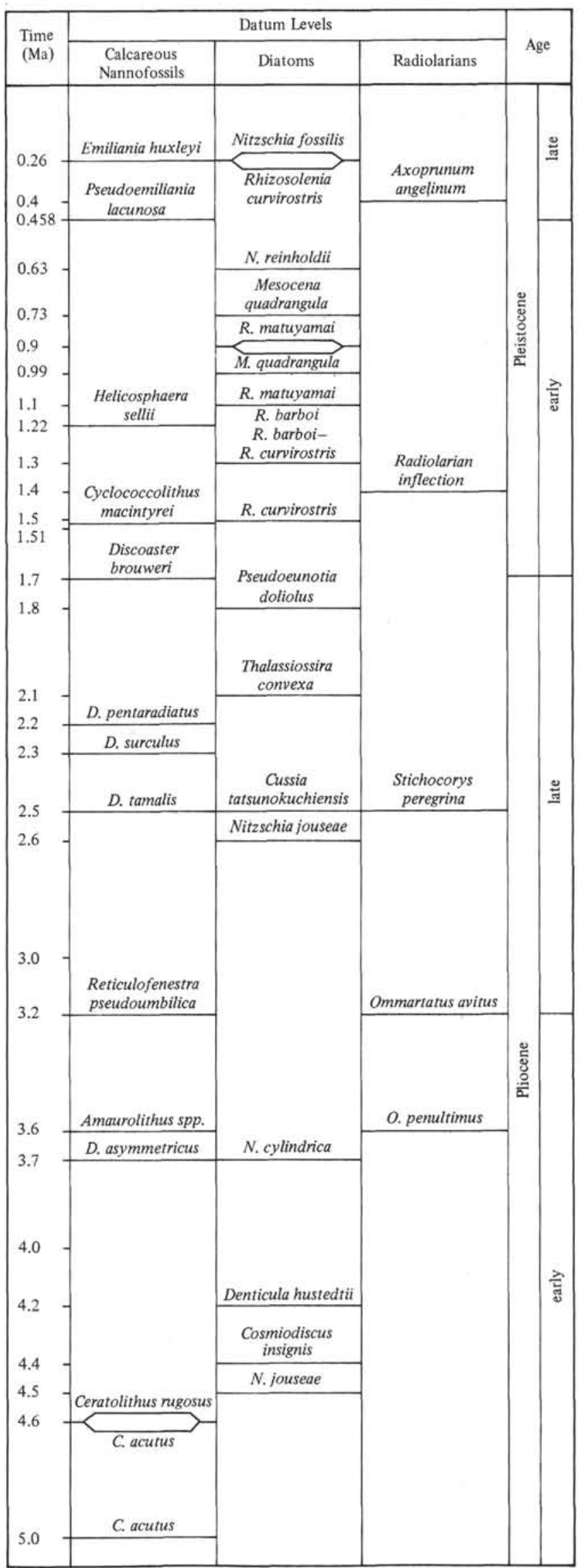


Table 2. Leg 64 datum levels.

\begin{tabular}{|c|c|c|c|}
\hline Species & $\begin{array}{l}\text { Appearance } \\
\text { Datum }\end{array}$ & $\begin{array}{l}\text { Time } \\
\text { (Ma) }\end{array}$ & Author \\
\hline \multicolumn{4}{|l|}{ Calcareous nannofossils } \\
\hline Emiliania huxleyi & FAD & 0.268 & Thierstein et al., 1977 \\
\hline Pseudoemiliania lacunosa & LAD & 0.458 & Thierstein et al., 1977 \\
\hline Helicosphaera sellii & LAD & 1.22 & Gartner, 1977 \\
\hline Cyclococcolithus macintyrei & LAD & 1.51 & Gartnet, 1977 \\
\hline Discoaster brouweri & LAD & 1.7 & Berggren et al., 1980 \\
\hline D. pentaradiatus & LAD & 2.2 & Haq and Berggren, 1978 \\
\hline D. surculus & LAD & 2.3 & Haq and Berggren, 1978 \\
\hline D. tamalis & LAD & 2.5 & Bukry, 1973 \\
\hline Reticulofenestra pseudoumbilica & LAD & 3.2 & Haq and Berggren, 1978 \\
\hline Amaurolithus spp. & LAD & 3.6 & Haq and Berggren, 1978 \\
\hline D. asymmetricus & FAD & 3.7 & Haq and Berggren, 1978 \\
\hline Ceratolithus rugosus & LAD & 4.6 & Haq and Berggren, 1978 \\
\hline C. acutus & FAD & 5 & Haq and Berggren, 1978 \\
\hline \multicolumn{4}{|l|}{ Diatoms and silicoflagellates } \\
\hline Nitzschia fossilis & $T$ & 0.26 & Koizumi, 1975a \\
\hline Rhizosolenia curvirostris & $\mathrm{T}$ & 0.26 & Barron, 1980 \\
\hline N. reinholdii & $\mathrm{T}$ & 0.63 & Barron, 1980 \\
\hline Mesocena quadrangula & $\mathrm{T}$ & 0.79 & Barron, 1980 \\
\hline R. matuyamai & $\mathbf{T}$ & 0.9 & Burckle et al., 1978 \\
\hline M. quadrangula & & 0.9 & Inferred from published ranges \\
\hline R. matuyamai & B & 0.99 & Burckle et al., 1978 \\
\hline R. barboi & $\mathrm{T}$ & 1.1 & Koizumi, 1975a \\
\hline$R$. barboi- $R$, curvirastris & E & 1.3 & Koizumi, 1975a \\
\hline R. curvirostris & $\bar{B}$ & 1.5 & Barron, 1980 \\
\hline Pseudoeunotia doliolus & B & 1.8 & Barron, 1980 \\
\hline Thalassiosira convexa & $\mathrm{T}$ & 2.1 & Barron, 1980 \\
\hline Cussia tatsunokuchiensis & $\mathrm{T}$ & 2.5 & Koizumi, 1975a \\
\hline N. jouseae & $\mathrm{T}$ & 2.6 & Barron, 1980 \\
\hline N. cylindrica & $\mathrm{T}$ & 3.7 & Inferred from published ranges \\
\hline Denticula hustedtii & $\mathrm{T}$ & 4.2 & Inferred from published ranges \\
\hline Cosmiodiscus insignis & $\mathrm{T}$ & 4.4 & Barron, 1980 \\
\hline N. jouseae & B & 4.5 & Barron, 1980 \\
\hline \multicolumn{4}{|l|}{ Radiolarians } \\
\hline Axoprunum angelinum & LAD & 0.4 & Hays and Opdike, 1976 \\
\hline Radiolarian inflection & & 1.4 & Molina-Cruz, this volume \\
\hline Stichocorys peregrina & LAD & 2.5 & Theyer et al., 1978 \\
\hline Ommatartus avitus & LAD & 3.2 & Molina-Cruz, this volume \\
\hline O. penultimus & LAD & 3.6 & Theyer et al. . 1978 \\
\hline
\end{tabular}

Note: $\mathrm{FAD}=$ first appearance datum, $\mathrm{LAD}=$ last appearance datum; $\mathrm{T}=$ top, $\mathrm{B}=$ bottom, $\mathrm{E}=$ evolutionary transition.

found a few meters above the unconformity, which indicates that the hemipelagic muds are slightly older than 3.2 Ma. Apparently, no sedimentation occurred at Sites 475 and 476 during the early Pliocene, between approximately 3.3 and $4.7 \mathrm{Ma}$.

\section{Oldest Sediments Recovered from the Guaymas Basin}

In the Guaymas Basin, very young sediments were recovered. Diatom datum levels provide the main biostratigraphic control. At Site 478, 317 meters of diatom oozes and turbidites were deposited during the last 0.26 m.y. and constituted most of the sediments penetrated $(340 \mathrm{~m})$ before the dolerite intrusion was reached. Matoba (this volume, Pt. 2) assigns a latest Pliocene age to the laminated mudstone recovered from the bottom of Hole 479, based on the presence of Globigerinoides obliquus and G. bollii and of sinistrally coiled Pulleniatina obliquiloculata in Sample 479-42,CC, which is tentatively correlated with the sinistral interval numbered L5 or L6 near the Olduvai Event of the Matuyama Reversed Epoch, and suggests an unconformity in Core 479-42. However, according to Schrader (this volume, Pt. 2), the oldest diatom-bearing sediments in Core
479-43 might not be older than around $0.99 \mathrm{Ma}$. Calcareous nannofossils are abundant in these mudstones, interlaminated with pure Coccolithus pelagicus oozes. Unfortunately, only long-ranging species were found.

\section{Rates of Sedimentation}

Table 3 estimates the rates of sedimentation through time at Sites 474 to 481 .

At the three sites off the tip of southern Baja California, sediments were deposited at constant rates, on average $50 \mathrm{~m} / \mathrm{m} . \mathrm{y}$., except at Site 474 , where Pleistocene sediments were deposited at rates five times higher.

In the Guaymas Basin, the rate of sedimentation at Site 478 during the late Pleistocene was higher than 1220 $\mathrm{m} / \mathrm{m} . \mathrm{y}$. At Site 481, a similar rate was calculated (higher than $1250 \mathrm{~m} / \mathrm{m} . \mathrm{y}$.); 327 meters of sediments were accumulated in less than 0.26 m.y. Pleistocene sediments at Sites 477 and 479 were deposited at slower (although high) rates.

High sedimentation rates explain the excellent preservation of the microfossils and nannofossils at Sites 478 and 481 , contrasted with their moderate to poor preservation at Sites 477 and 479 .

\section{REFERENCES}

Barron, J. A., 1980. Lower Miocene to Quaternary diatom biostratigraphy of Leg 57, off northeastern Japan, Deep Sea Drilling Project. In Scientific Party, Init. Repts. DSDP, 56, 57, Pt. 2: Washington (U.S. Govt. Printing Office), 641-686.

Berggren, W. A., Burckle, L. H., et al., 1980. Towards a Quaternary time scale. Quat. Res., 13:277-302.

Bukry, D., 1975. Coccolith and silicoflagellate stratigraphy, Northwestern Pacific Ocean, Deep Sea Drilling Project Leg 32. In Larson, R. L., Moberly, R. et al., Init. Repts. DSDP, 32: Washington (U.S. Govt. Printing Office), 677-701.

Burckle, L. H., Hammond, S. R., and Seyb, S. M., 1978. A stratigraphically important new diatom from the Pleistocene of the North Pacific. Pacific Sci., 32(no. 2):209-214.

Gartner, S., 1977. Calcareous nannofossil biostratigraphy and revised zonation of the Pleistocene. Mar. Micropaleontol., 2:1-25.

Haq, B. U., and Berggren, W. A., 1978. Late Neogene calcareous plankton biochronology of the Rio Grande Rise (South Atlantic Ocean). J. Paleontol., 52(no. 6):1167-1194.

Hays, J. D., and Opdyke, N. D., 1967. Antarctic radiolarians, magnetic reversals and climatic changes. Science, 158(no. 3804): 1001-1011.

Koizumi, I., 1975a. Late Cenozoic diatom biostratigraphy in the circum North Pacific region. Geol. Soc. Japan J., 81(no. 10): 617-627.

, 1975b. Neogene diatoms from the western margin of the Pacific Ocean, Leg 31, Deep Sea Drilling Project. In Karig, D. E. Ingle, J. C., Jr., et al., Init. Repts. DSDP, 31: Washington (U.S. Govt. Printing Office), 779-819.

Theyer F., Mato, C. Y., and Hammond, S. R., 1978. Paleomagnetic and geochronologic calibration of the latest Oligocene to Pliocene radiolarian events, Equatorial Pacific. Mar. Micropaleontol., 3:377-395.

Thierstein, H. R., Geitzenauer, K. R., and Molfino, B., 1977. Global synchroneity of late Quaternary coccolith datum levels: Validation by oxygen isotopes. Geology, 5:400-405. 

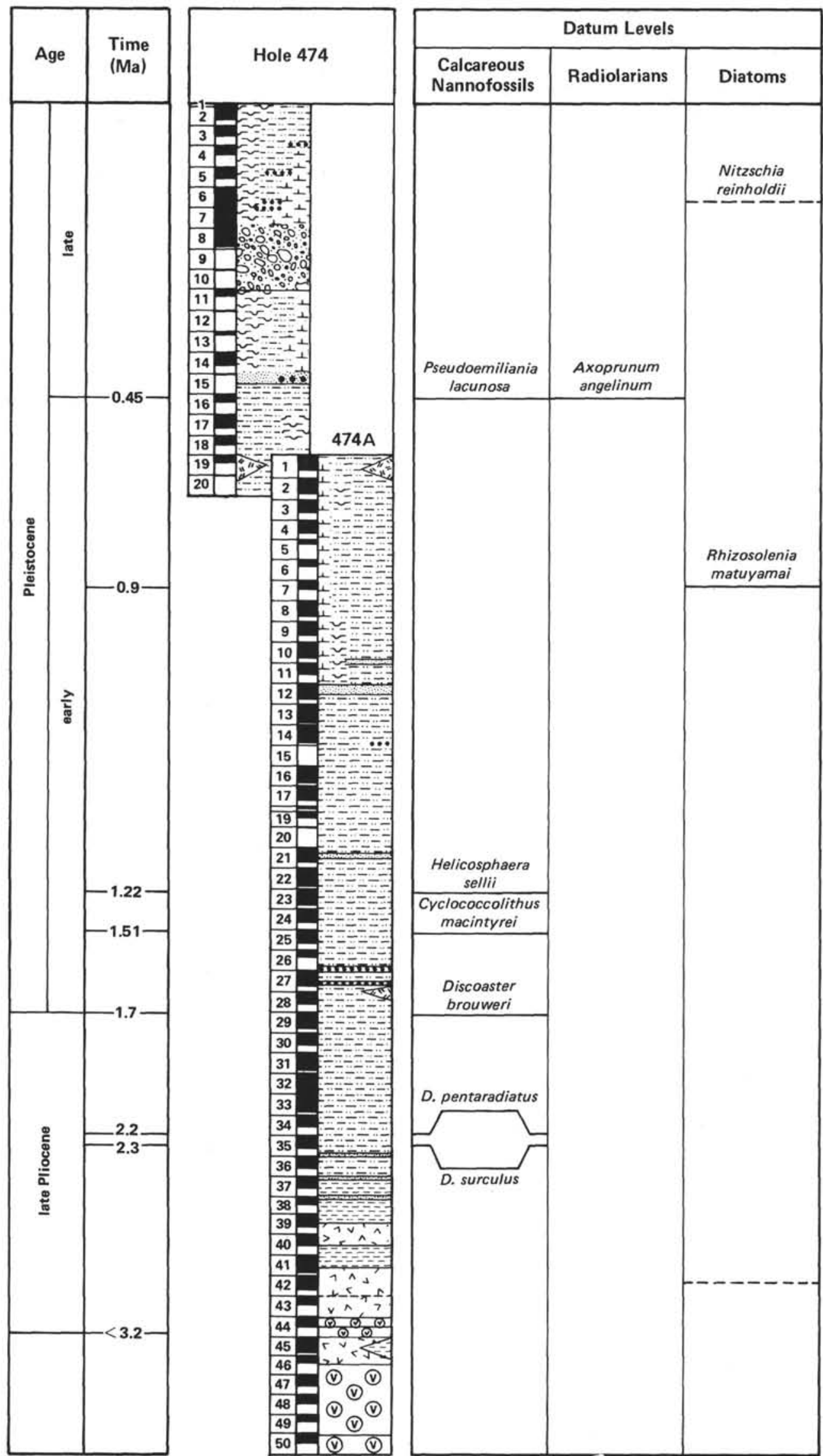

- - Dubious

datum level

Figure 2. Biostratigraphic synthesis, Site 474 . These columns have been revised from those of the site chapters. 


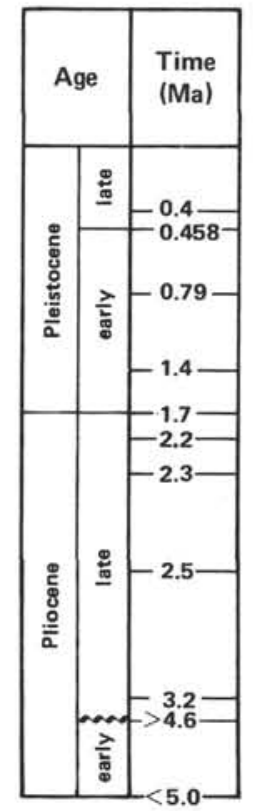

---- Dubious datum leve

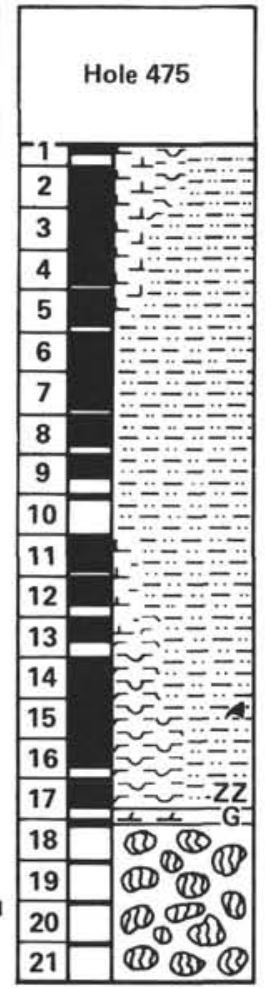

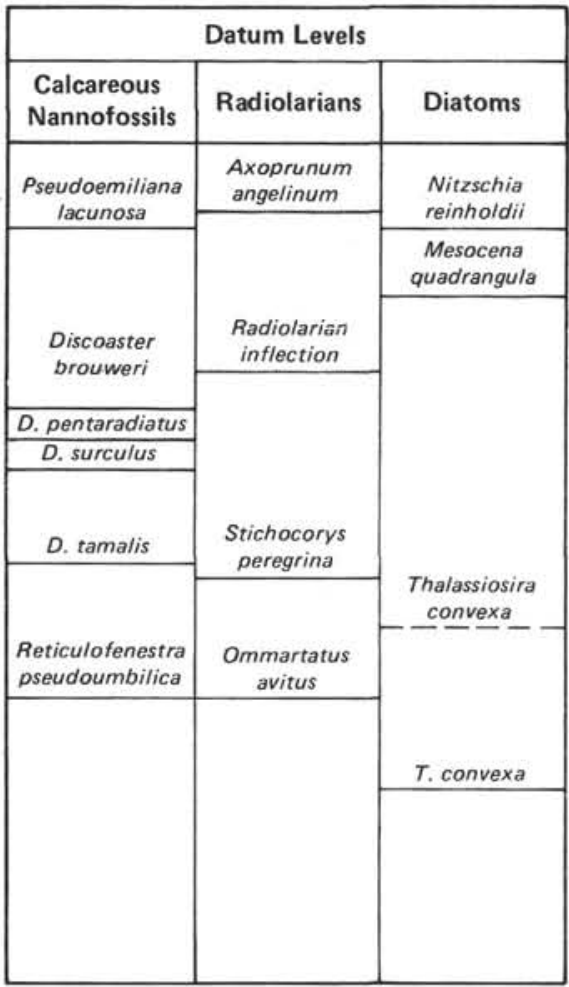

Figure 3. Biostratigraphic synthesis, Site 475. These columns have been revised from those of the site chapters.
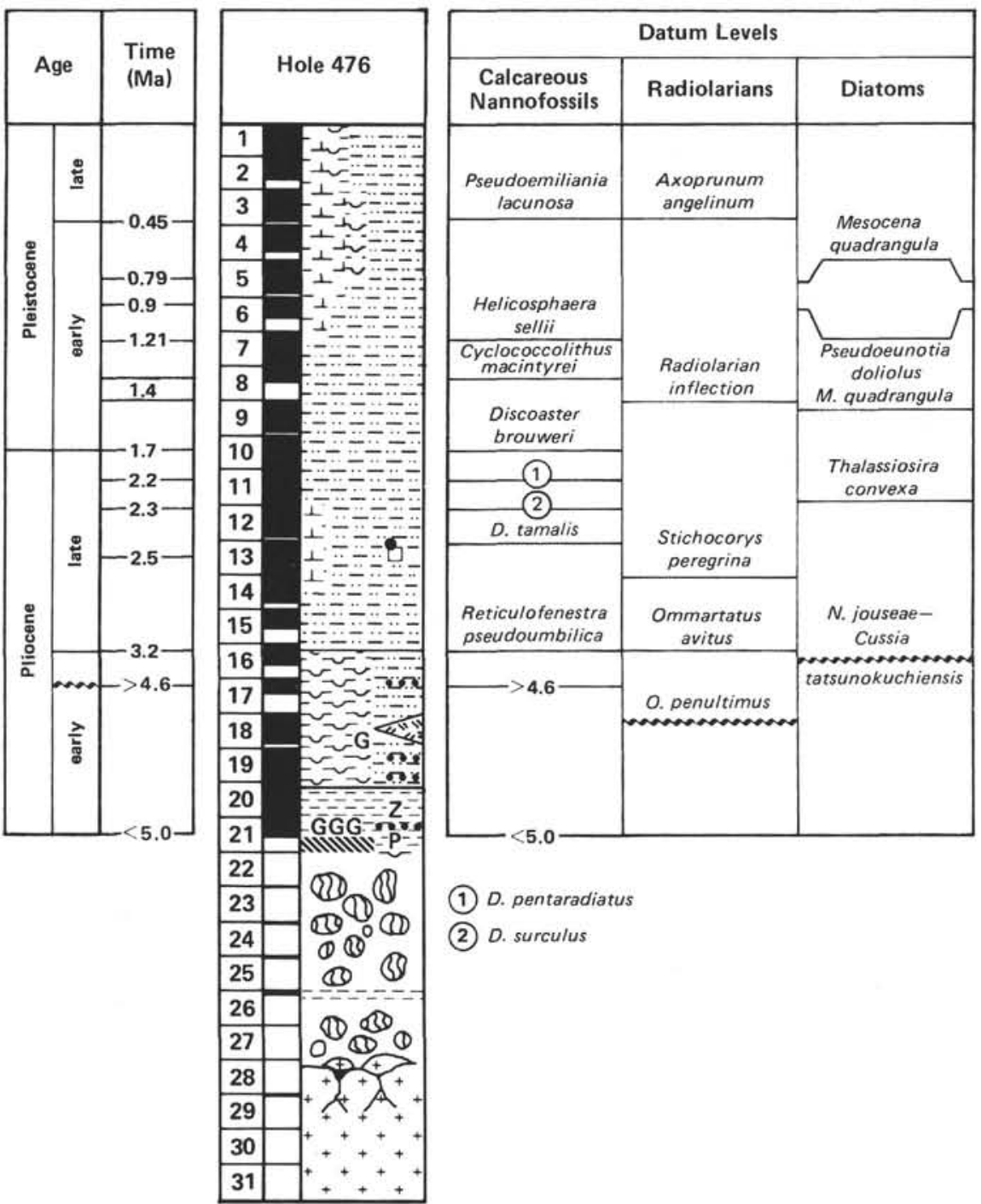

Figure 4. Biostratigraphic synthesis, Site 476. These columns have been revised from those of the site chapters. 


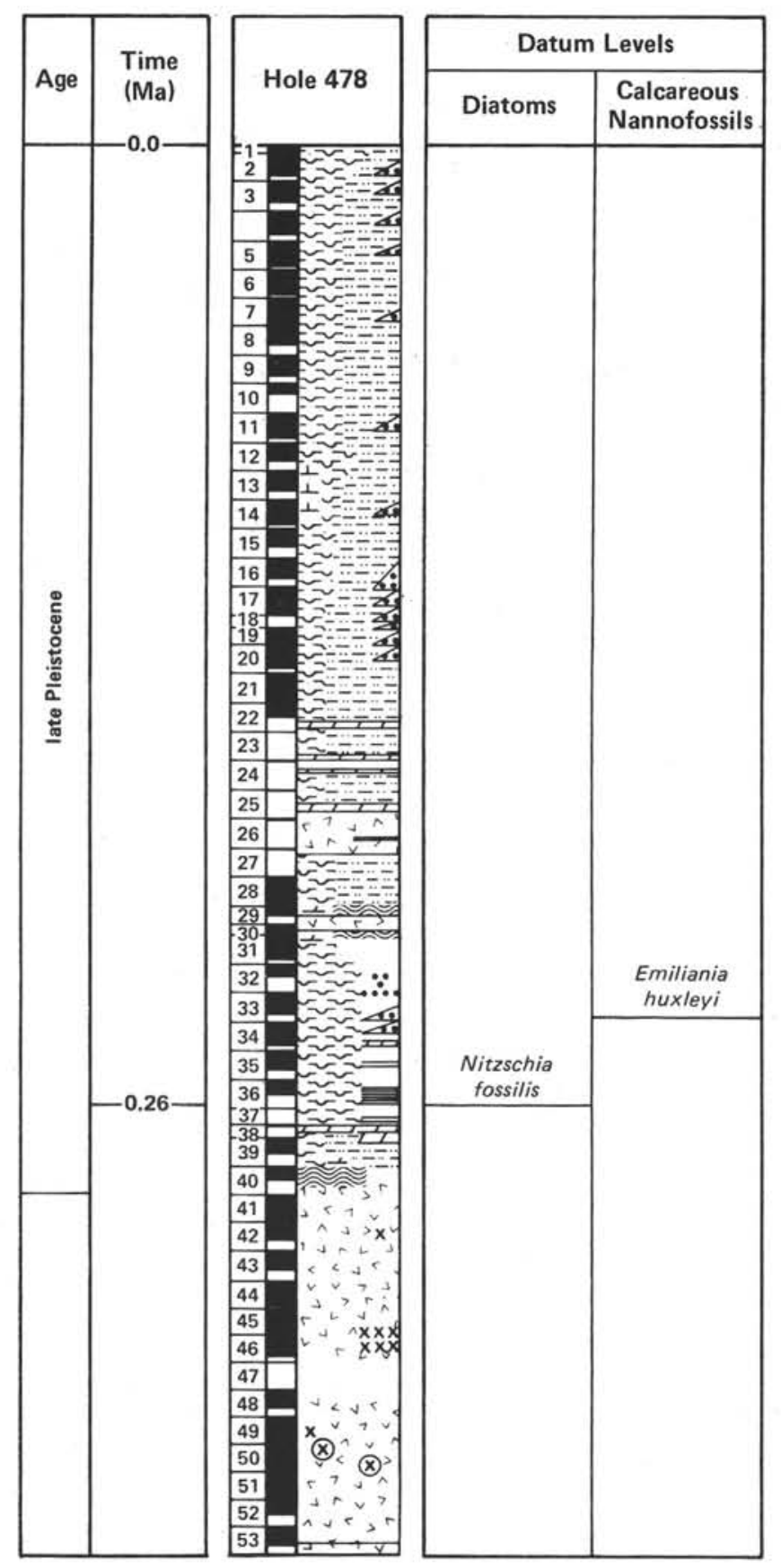

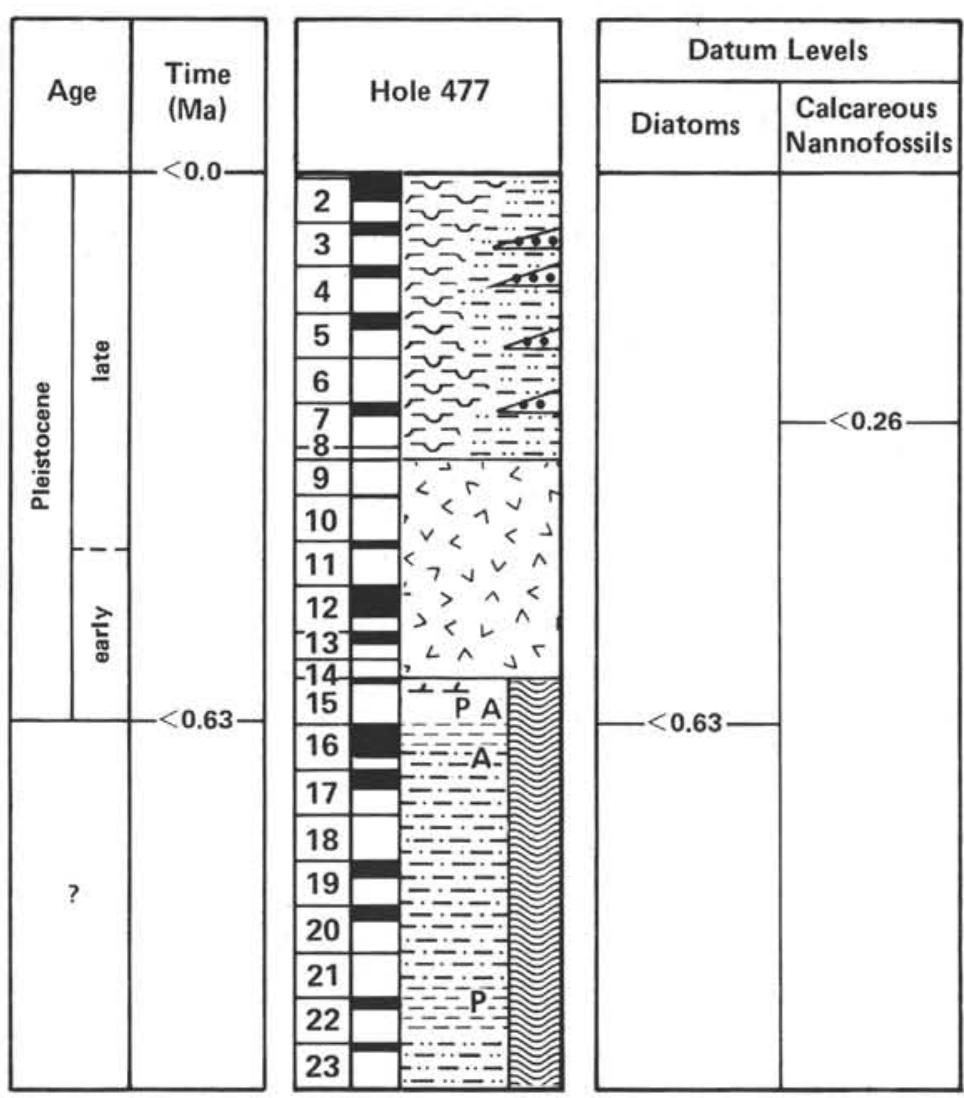

Figure 5. Biostratigraphic synthesis, Site 477. These columns have been revised from those of the site chapters.
Figure 6. Biostratigraphic synthesis, Site 478. These columns have been revised from those of the site chapters. 


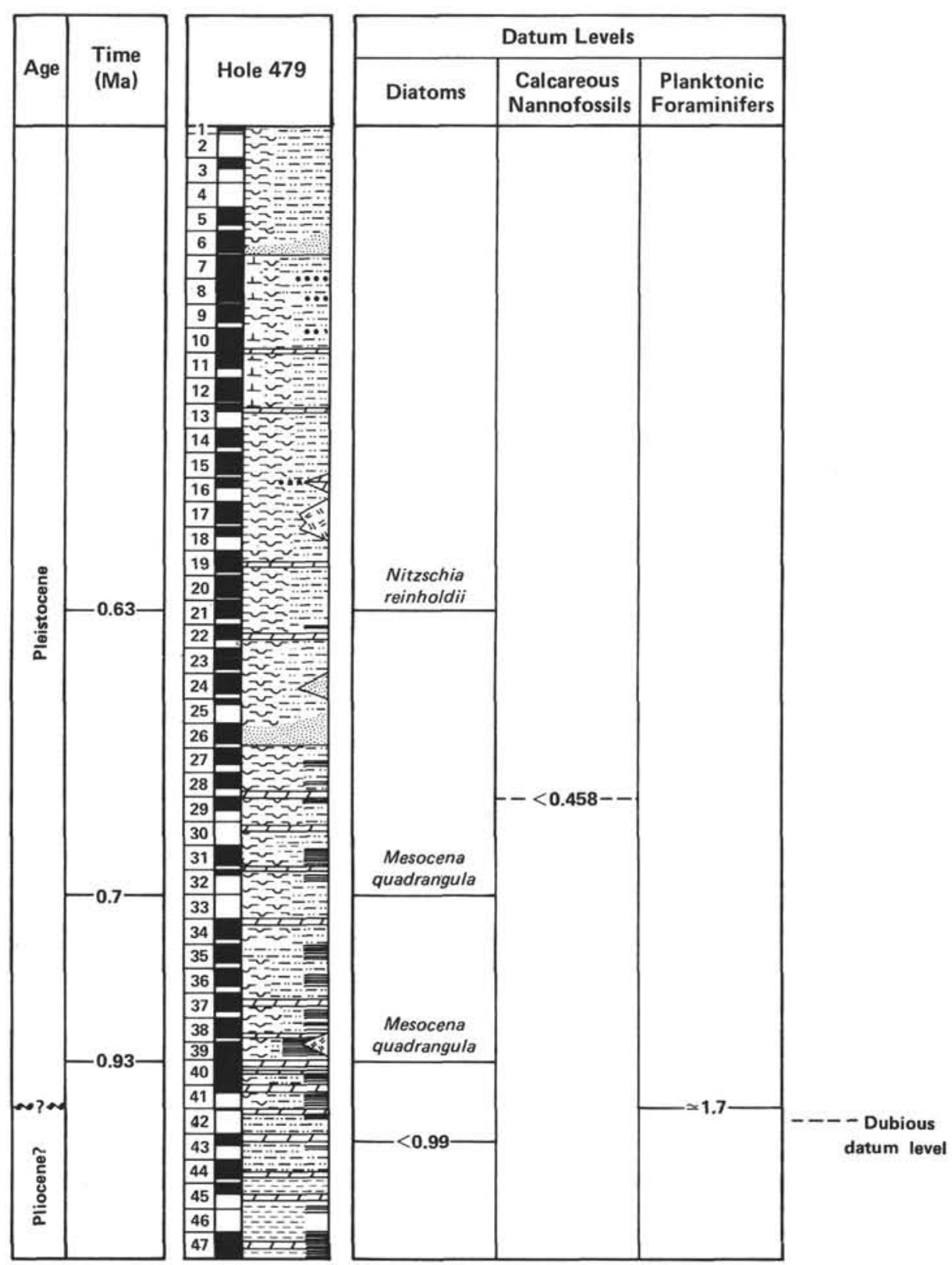

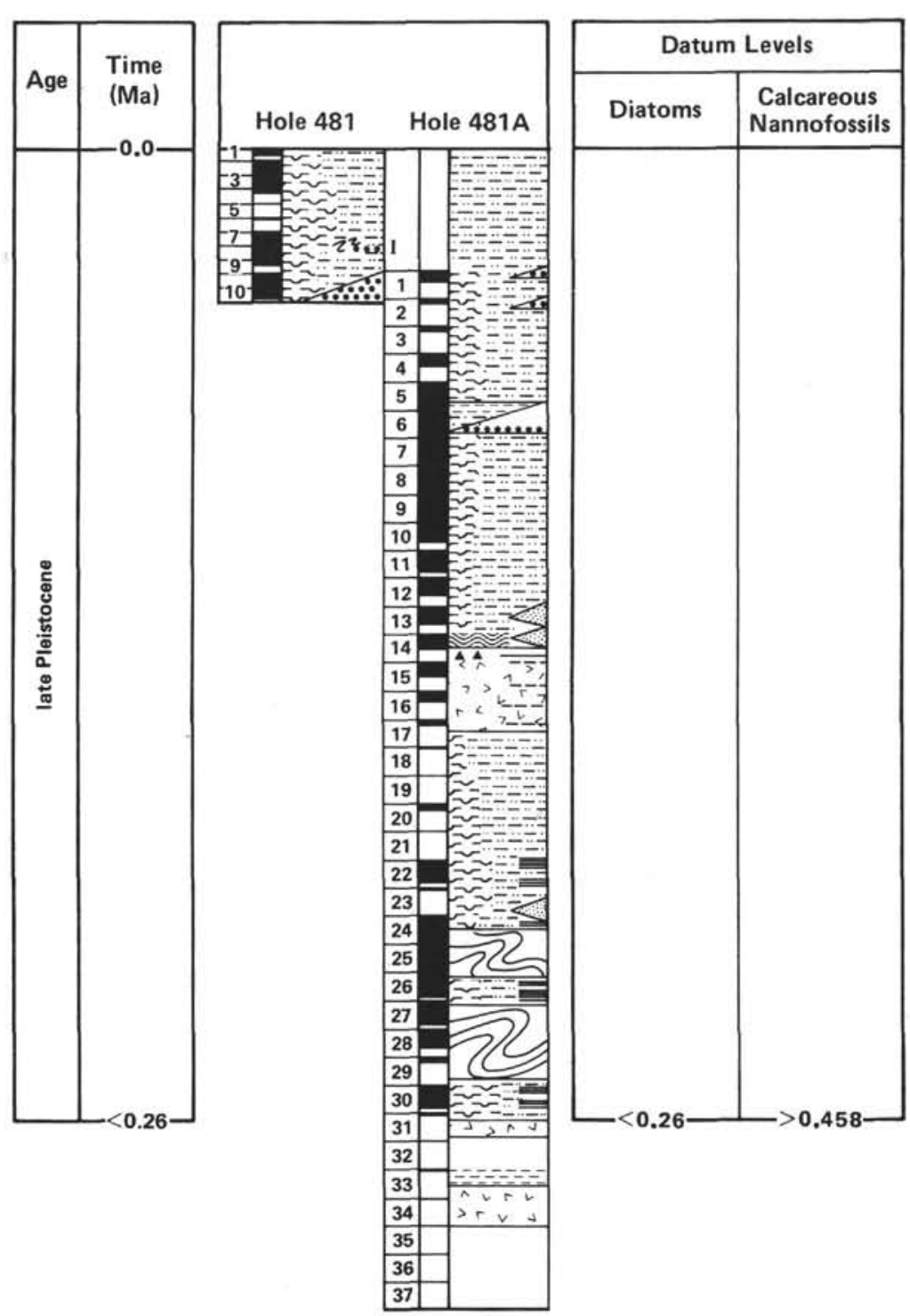

Figure 8. Biostratigraphic synthesis, Site 481 . These columns have been revised from those of the site chapters. 
M.-P. AUBRY, Y. MATOBA, A. MOLINA-CRUZ, H. SCHRADER

Table 3. Estimations of averaged rates of sedimentation (in m/m.y.) at DSDP Leg 64 sites.

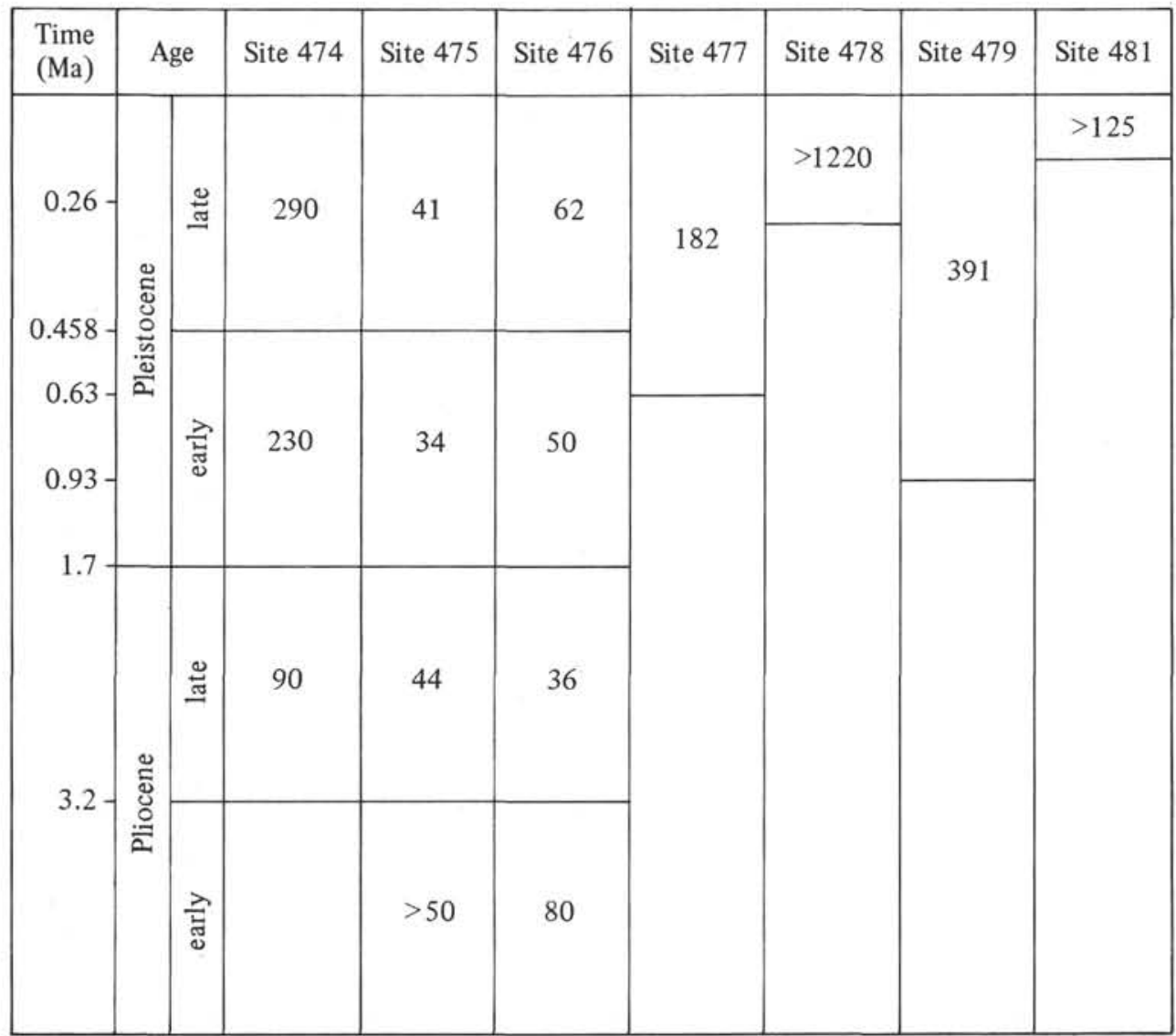

Note: Presence of slide section at about 0.5 m.y. in Site 474 (Moore, et al., this volume, Pt. 2) contributes to high rates. 